\title{
Effect of Different Irrigation Level on Growth, Yield and Water Use Efficiency of Tuberose in Lower Gangetic Plain of West Bengal, India
}

\author{
Rubina Khanam ${ }^{1}$, Dipa Kundu ${ }^{2 *}$, Umalaxmi Thingujam ${ }^{1}$ and S.K. Patra ${ }^{1}$ \\ ${ }^{1}$ ICAR-National Rice Research Institute, Cuttack, Odisha 753006, India \\ ${ }^{2}$ Department of Agricultural Chemistry and Soil Science, Bidhan Chandra Krishi \\ Viswavidyalaya, Mohanpur, Nadia-741252, West Bengal, India \\ *Corresponding author
}

\section{A B S T R A C T}

\section{Keywords}

Irrigation level,

Water

requirement,

Flower

production,

Tuberose,

Economics.

Article Info

Accepted:

19 June 2017

Available Online:

10 August 2017
The state of West Bengal has 2.7 per cent of geographical area and 7.5 per cent of water resources. Among the various natural resources, water is considered the most precious and vulnerable input for sustain biological productivity, maintain environmental quality and sustain plant, animal, human health and augmented agricultural production., a field experiment was conducted at the Regional Research Station, Gayeshpur, BCKV during the winter season of 2013-2014 to assess water Requirement and water use efficiency of tuberose. The application of irrigation based on IW/CPE ratio revealed that plant height of tuberose consistently increased with the increasing moisture regimes. However, the highest plant height of 54.97 was obtained with the irrigation at 1.0IW/CPE ratio, which was superior to other irrigation treatments. Maximum plant height, irrespective of irrigation schedules was recorded by Prajwal variety, which was superior to other varieties namely Calcutta single and Calcutta double were at par under study. The interaction effects between the irrigation schedule and the varieties were not significant. From this study it is indicated that the economic yield of tuberose under higher moisture level was not high enough/ or optimal in response to the higher irrigation regimes, thereby giving lesser gross return as well as the net return values as compared to the lower moisture regime.

\section{Introduction}

Tuberose (Polianthes tuberosa L.) is more popularly known as 'Rajanigandha' one of the most important commercially grown traditional flower crop in India. The lingering delightful fragrance and its excellent keeping quality are the predominant characteristic this crop.It is commercially grown for its attractive and luring cut flowers and also for the production of bulbs. This species usually blooms during summer and fall months, producing showy conspicuous fragrant yield of cut flowers of high marketable value due to the lack of other flowering bulbs in summer and autumn. The evapotranspiration for different seasonal crops were studied e.g. Sorghum by Gorad et al., (1995), Sesame by Rao and Sondge (1995), Safflower by Sondge et al., (1992), Corn by Suneetha Devi and Rao (2002), Groundnut noted by Palanisami and Chandrasekaran (2004) and Sugarcane said by Selvaraj and Palanisami, (2003) under different climatic and local conditions. Less work had been done for estimation of water requirement for seasonal and annual crops like tuberose under the West Bengal condition. The crops selected for the study is 
an important crop in this region and grown on large area. So there is urgent need to study the evapotranspiration for crops. The prediction the water requirement of this crop can help in protection from water shortage during the hot season and to utilize the available water resources efficiently. So an attempt was made to estimate the water requirement of tuberose (Polianthes tuberosa L.) and performance of different varieties according to the local and climatic conditions of alluvial zone of West Bengal.

\section{Materials and Methods}

The experimental was conducted at Departmental Experimental Field, department of Agricultural Chemistry and Soil Science, Faculty of Agriculture, Bidhan Chandra Krishi Viswavidyalaya, Mohanpur, Nadia, under the jurisdiction of lower Gangetic plain of West Bengal to study water Requirement of tuberose. The farm is situated at $22^{\circ} 56^{\prime}$ North latitude and $88^{\circ} 32^{\prime}$ East longitude with an average elevation of 9.75 meter above Mean Sea Level. Tuberose (Polianthes tuborosa L.) is a perennial crop. The planting job was completed on $9^{\text {th }}$ March 2012 during the kharif season. The soil of the experimental site is sandy loam in texture, well drained with medium fertility. The soil reaction is neutral and the available nutrient status is satisfactory. The relevant physical and physico-chemical properties of soil profile were estimated following the standard method as described by (Jackson, 1973). In this experiment plant $\mathrm{x}$ plant and row $\mathrm{x}$ row spacing was $0.03 \mathrm{~m} \mathrm{x} 0.03 \mathrm{~m}$ and $0.4 \mathrm{~m}$ irrigation channel. The experiment consisted of four treatments viz., $\mathrm{T}_{1}: 0.4 \mathrm{IW} / \mathrm{CPE}$ (Depth of irrigation $3 \mathrm{~cm}$ ), $\mathrm{T}_{2}: 0.8 \mathrm{IW} / \mathrm{CPE}$, $\mathrm{T}_{3}: 1.0 \mathrm{IW} / \mathrm{CPE}$ was laid out in a Factorial RBD. Three verities of tuberose were taken for our experiment. V1: Prajwal (Polianthes tuberose L.), V2: Calcutta single (Polianthes tuberose L.) and V3: Calcutta double
(Polianthes tuberose L.). The recommended fertilizer doses of 200:200:150 kg NPK/ha were applied in form of urea, muriate of potash and single superphosphate for N, P and $\mathrm{K}$, respectively. The full amount of $\mathrm{P}$ and $\mathrm{K}$ and one third of $\mathrm{N}$ should apply in the form of basal dose and rest in four-split doses as top dressing after 25 - 30 days interval. The data obtained were subjected to the proper statistical analysis (Gomez and Gomez, 1984).

\section{Growth characteristics}

Plant height, Number of leaves/ Clump, Fresh weight of leaves, Spike Length, Spike Diameter, Number of spike / Plot, Number of florets/ Spike, Diameter of individual floret.

\section{Water requirement of crops}

The crop water requirement is mainly depends upon the crop type, stages of growth and its evaporative demand. To calculate the evaporative demand the USWB Class A pan (circular) was used. The evaporation pan provides a measurement of the integrated effect of radiation, Wind, temperature and humidity on evaporation from a specific open water surface studied by Doorenbos and Pruitt (1977). Similarly, according to Suneetha Devi and Rao, (2002) pan evaporation estimates are easily available, reliable, and more convenient to measure and also combine the effect of all meteorological parameters into a single entity. So the evaporation data from the USWB Class A pan is consider for the study.

The estimate of crop water requirement is one of the basic needs for crop planning in common areas and planning of any irrigation project. According to Doorenbus and Pruitt (1977):

$\mathrm{ETc}=\mathrm{Kc} \times \mathrm{ETo} \ldots \ldots \ldots \ldots$ (1) 
Where,

$\mathrm{ETc}=$ Crop water requirements to meet actual evaporation demand.

$\mathrm{Kc}=$ Crop coefficient and

ETo $=$ Reference crop evapotranspiration

Again, ETo $=$ Kpan $\times$ Epan

Where,

ETo $=$ Reference crop evapotranspiration

Kpan $=$ Pan co-efficient

Epan $=$ Pan evaporation

The influence of the climate on crop water needs is given by the reference crop evapotranspiration (ETo). The ETo is usually expressed in millimetres per unit of time, i.e. $\mathrm{mm} /$ day, $\mathrm{mm} / \mathrm{month}$, or $\mathrm{mm} / \mathrm{season}$.

Equation (1) is used to compute the daily value of ETc. From the daily values, monthly values of ETc for each plant on any month can be compute by multiplying the daily values of ETc with number of days of that month, area occupied by each plant and the percentage of canopy area occupied by the plant.

\section{Irrigation requirement of different varieties of tuberose}

The irrigation requirement of crop (IR) can be obtained from the following formula was given by Michael, 1970) and stated below:

$\mathrm{IR}=\mathrm{ETc}-(\mathrm{M}+\mathrm{Gw}+\mathrm{ER})$

Where,

$\mathrm{M}=$ Available soil moisture content in root zone of crops
$\mathrm{Gw}=$ Ground water contribution and

$\mathrm{ER}=$ Effective rainfall

Ground water contribution $(\mathrm{Gw})$ to meet the irrigation requirement of crop is neglected since in the area under study, water table lies more than $2.5 \mathrm{~m}$ below the ground water surface. It is assumed that the carry over moisture content before and after a decision period remain same as it is difficult to get the value of "M" under variable weather condition in farmers' field condition. Thus the net irrigation requirement (IR) is compute as,

$\mathrm{IR}=\mathrm{ETc}-\mathrm{ER}$

So, monthly net volume of water to be applied as irrigation is,

$\mathrm{V}=(\mathrm{ETc}-\mathrm{ER}) \times \mathrm{A} \times \mathrm{Wp}$

Where,

$\mathrm{V}=$ Monthly irrigation requirement

$\mathrm{A}=$ Area occupied by each plant

$\mathrm{Wp}=$ Percentage of canopy area which is assumed as 50\% during initial crop growth stage and $75 \%$ during other stage (Dhal, 1999., Anonymous, 2002). The term ETc and ER are defined earlier.

\section{Results and Discussion}

\section{Plant height}

The application of irrigation based on IW/CPE ratio revealed that plant height of tuberose consistently increased with the increasing moisture regimes (Table 1). However, the highest plant height of 54.97 was obtained with the irrigation at 1.0IW/CPE ratio, which was superior to other irrigation 
treatments. Similarly, significantly the lowest plant height $(53.87 \mathrm{~cm})$ was register at lower moisture regime of $0.4 \mathrm{IW} / \mathrm{CPE}$ which was at par with $0.8 \mathrm{IW} / \mathrm{CPE}$ ratios. The plant height among the varieties tested was significant with each other. However, maximum plant height, irrespective of irrigation schedules was recorded by Prajwal variety, which was superior to other varieties namely Calcutta single and Calcutta double were at par under study. The interaction effects between the irrigation schedule and the varieties were not significant. However, maximum plant height was recorded by Prajwal at irrigation schedule 1.0 IW/CPE.

\section{Leaf per plant}

The application of irrigation based on IW/CPE ratio revealed that the leaf/plant of tuberose consistently increased with increasing moisture regime (Table 1). However, the highest leaf per plant of 105.12 was obtained with the irrigation schedule 1.0 IW/CPE which was superior to other irrigation treatments. Similarly, significantly the lowest leaf per plant was recorded in the irrigation schedule of 0.4 IW/CPE ratios. Among the three varieties, Calcutta double appeared to be the highest yielder of leaf per plant as compared to the other two varieties. The variety Prajwal, irrespective of irrigation levels, showed that lowest yielder in terms of leaf per plant. The variety Calcutta single showed the intermediate value. The interaction between the irrigation levels and varieties as regard to the number of leaf per plant was non-significant. However, variety Calcutta double showed the highest value of leaf per plant irrigated at higher moisture level.

\section{Stalk length}

Maximum length of stalk $(79.7 \mathrm{~cm})$ was observed in the irrigation schedule of 1.0
IW/CPE which was superior to other two irrigation schedules (Table 2). The former two irritation treatments as regards to stalk length were at par with each other. The stalk length of three varieties under examination was significantly influenced. However, the maximum stalk length was recorded by the variety Prajwal $(87.2 \mathrm{~cm})$ followed by that of Calcutta double $(73.1 \mathrm{~cm})$ and the least by the variety Calcutta single $(69.8 \mathrm{~cm})$. The interaction between the irrigation schedules and the varieties on stalk length was not significant. However, maximum stalk length of $80.6 \mathrm{~cm}$ was recorded by Calcutta double at irrigation schedule of 1.0 IW/CPE.

\section{Stalk diameter}

The stalk diameter of tuberose was not statistically influenced under three irrigation levels (Table 2). However, maximum diameter of stalk $(3.38 \mathrm{~cm})$ was found by the irrigation schedule of 1.0 IW/CPE followed by that of $3.35 \mathrm{~cm}$ at $0.8 \mathrm{IW} / \mathrm{CPE}$ and $3.30 \mathrm{~cm}$ at $0.4 \mathrm{IW} / \mathrm{CPE}$. The stalk diameter of three varieties of tuberose, irrespective of irrigation schedules, was significantly influenced. The highest diameter $(3.62 \mathrm{~cm})$ was registered by the variety Calcutta double and that was superior to other two varieties under tested. The two varieties namely, Prajwal and Calcutta single in promoting the stalk diameter regardless of irrigation levels were on par. The interaction effects between the irrigation levels and varieties on stalk diameter were non-significant.

\section{Diameter of spike}

The diameter of spike, irrespective of the varieties of tuberose, was not significant under the influenced of irrigation levels based on IW/CPE ratios (Table 3). Maximum diameter of spike $(3.35 \mathrm{~cm})$ was observed at 1.0 IW/CPE ratio and the minimum diameter of spike $(3.25 \mathrm{~cm})$ was shown at irrigation 
schedule of $0.4 \mathrm{IW} / \mathrm{CPE}$ ratios. The varietal effects in promoting the diameter of spike, irrespective of irrigation levels, were significantly influenced. The highest diameter of $3.41 \mathrm{~cm}$ was recorded by Calcutta double followed by that of $3.36 \mathrm{~cm}$ by Calcutta single and $3.15 \mathrm{~cm}$ by Prajwal. The varieties, Calcutta single and Prajwal, as regards to the diameter of spike was at par with each other. The interaction between the irrigation levels and varieties on diameter of spike was not significantly influenced.

\section{Flower per spike}

The number of flower per spike, irrespective of the varieties of tuberose, was not significant under the influenced of irrigation levels based on IW/CPE ratios (Table 3). Maximum flower per spike (31.80) was observed at $1.0 \mathrm{IW} / \mathrm{CPE}$ ratio and the minimum number of flower/ spike (31.40) was recorded by irrigation schedule of 0.8 IW/CPE ratios. The varietals effects in promoting the number of flower per spike, irrespective of irrigation levels, were significantly influenced. The highest number of flower per spike (33.1) was recorded by Calcutta double followed by that of Calcutta single (31.50) and Prajwal (30.20). The varieties, Calcutta single and Prajwal as regards to the flower per spike were at par. The interaction between the irrigation levels and varieties on number of flowers per spike was not significant.

Table.1 Effects of irrigation levels on plant height and leaf per plant of three varieties of tuberose

\begin{tabular}{|c|c|c|c|c|c|c|c|c|}
\hline \multirow[t]{3}{*}{ Treatment } & \multicolumn{4}{|c|}{ Plant height $(\mathrm{cm})$} & \multicolumn{4}{|c|}{ Leaf/plant } \\
\hline & \multicolumn{3}{|c|}{ Variety } & Mean & \multicolumn{3}{|c|}{ Variety } & Mean \\
\hline & V1 & $\mathrm{V} 2$ & V3 & & V1 & V2 & V3 & \\
\hline I1 & 55.32 & 53.60 & 52.71 & 53.87 & 79.2 & 109.4 & 118.7 & 102.46 \\
\hline $\mathrm{I} 2$ & 55.61 & 53.22 & 52.75 & 53.86 & 86.8 & 108.0 & 118.9 & 104.54 \\
\hline I3 & 56.29 & 54.95 & 53.67 & 54.97 & 82.5 & 111.9 & 122.1 & 105.52 \\
\hline Mean & 55.74 & 53.92 & 53.04 & - & 82.84 & 109.78 & 119.91 & - \\
\hline \multirow[b]{2}{*}{$\operatorname{SEm}( \pm)$} & $\mathrm{I}$ & $\mathrm{V}$ & $\mathrm{Ix} \mathrm{V}$ & & $\mathrm{I}$ & $\mathrm{V}$ & $\mathrm{Ix} \mathrm{V}$ & \\
\hline & 0.27 & 0.27 & 0.47 & & 1.76 & 1.76 & 3.04 & \\
\hline $\mathrm{CD}(5 \%)$ & 0.81 & 0.81 & NS & & NS & 5.26 & $\mathrm{NS}$ & \\
\hline
\end{tabular}

Note: $\mathrm{I} 1=$ Irrigation at $0.4 \mathrm{IW} / \mathrm{CPE}, \mathrm{I} 2=$ Irrigation at $0.8 \% \mathrm{IW} / \mathrm{CPE}, \mathrm{I} 3=$ Irrigation at $1.0 \mathrm{IW} / \mathrm{CPE}$ and $\mathrm{V} 1=$ Variety Prajwal, V2 = Variety Calcutta single, V3 = Variety Calcutta double

Table.2 Effects of irrigation levels on stalk length and stalk diameter of three varieties of tuberose

\begin{tabular}{|c|c|c|c|c|c|c|c|c|}
\hline \multirow[t]{3}{*}{ Treatment } & \multicolumn{4}{|c|}{ Stalk length $(\mathrm{cm})$} & \multicolumn{4}{|c|}{ Stalk diameter $(\mathrm{cm})$} \\
\hline & \multicolumn{3}{|c|}{ Variety } & \multirow[t]{2}{*}{ Mean } & \multicolumn{3}{|c|}{ Variety } & \multirow[t]{2}{*}{ Mean } \\
\hline & V1 & $\mathrm{V} 2$ & V3 & & V1 & $\mathrm{V} 2$ & V3 & \\
\hline I1 & 88.0 & 69.5 & 68.6 & 75.36 & 3.1 & 3.2 & 3.6 & 3.30 \\
\hline $\mathrm{I} 2$ & 86.2 & 69.2 & 70.1 & 75.15 & 3.2 & 3.2 & 3.6 & 3.35 \\
\hline I3 & 87.5 & 70.9 & 80.6 & 79.67 & 3.2 & 3.3 & 3.6 & 3.38 \\
\hline Mean & 87.22 & 69.85 & 73.11 & & 3.18 & 3.24 & 3.62 & \\
\hline \multirow{3}{*}{$\frac{\operatorname{SEm}( \pm)}{\mathrm{CD}(5 \%)}$} & I & $\mathrm{V}$ & $\mathrm{I} \times \mathrm{V}$ & & I & $\mathrm{V}$ & $\mathrm{I} \times \mathrm{V}$ & \\
\hline & 1.18 & 1.18 & 2.04 & & 0.03 & 0.03 & 0.06 & \\
\hline & 3.52 & 3.52 & NS & & NS & 0.10 & NS & \\
\hline
\end{tabular}

Note: I1 = Irrigation at $0.4 \mathrm{IW} / \mathrm{CPE}, \mathrm{I} 2=$ Irrigation at $0.8 \% \mathrm{IW} / \mathrm{CPE}, \mathrm{I} 3=$ Irrigation at $1.0 \mathrm{IW} / \mathrm{CPE}$ and $\mathrm{V} 1=$ Variety Prajwal, V2 = Variety Calcutta single, V3 = Variety Calcutta double 
Table.3 Effects of irrigation levels on diameter of spike and flower per spike of Three varieties of tuberose

\begin{tabular}{|c|c|c|c|c|c|c|c|c|}
\hline \multirow[t]{3}{*}{ Treatment } & \multicolumn{4}{|c|}{ Diameter of spike $(\mathrm{cm})$} & \multicolumn{4}{|c|}{ Flower/spike } \\
\hline & \multicolumn{3}{|c|}{ Variety } & \multirow[t]{2}{*}{ Mean } & \multicolumn{3}{|c|}{ Variety } & \multirow{2}{*}{ Mean } \\
\hline & V1 & $\mathrm{V} 2$ & V3 & & V1 & V2 & V3 & \\
\hline I1 & 3.1 & 3.3 & 3.4 & 3.27 & 30.8 & 31.5 & 32.5 & 31.60 \\
\hline $\mathrm{I} 2$ & 3.2 & 3.4 & 3.4 & 3.33 & 30.3 & 31.4 & 32.6 & 31.39 \\
\hline I3 & 3.1 & 3.3 & 3.5 & 3.35 & 29.6 & 31.6 & 34.3 & 31.84 \\
\hline Mean & 3.15 & 3.36 & 3.41 & - & 30.22 & 31.50 & 33.12 & - \\
\hline \multirow{3}{*}{$\frac{\operatorname{SEm}( \pm)}{\mathrm{CD}(5 \%)}$} & I & V & $\mathrm{I} \times \mathrm{V}$ & & I & $\mathrm{V}$ & $\mathrm{I} \times \mathrm{V}$ & \\
\hline & 0.05 & 0.05 & 0.08 & & 0.38 & 0.38 & 0.66 & \\
\hline & $\mathrm{NS}$ & 0.14 & NS & & NS & 1.14 & NS & \\
\hline
\end{tabular}

Note: $\mathrm{I} 1=$ Irrigation at $0.4 \mathrm{IW} / \mathrm{CPE}, \mathrm{I} 2=$ Irrigation at $0.8 \% \mathrm{IW} / \mathrm{CPE}, \mathrm{I} 3=$ Irrigation at $1.0 \mathrm{IW} / \mathrm{CPE}$ and $\mathrm{V} 1=$ Variety Prajwal, V2 = Variety Calcutta single, V3 = Variety Calcutta double

Table.4 Effects of irrigation levels on spike per plot of three varieties of tuberose

\begin{tabular}{|c|c|c|c|c|}
\hline \multirow[t]{3}{*}{ Treatment } & \multicolumn{4}{|c|}{ Spike /plot } \\
\hline & \multicolumn{3}{|c|}{ Variety } & \multirow{2}{*}{ Mean } \\
\hline & V1 & $\mathrm{V} 2$ & V3 & \\
\hline I1 & 26.30 & 31.90 & 33.50 & 30.57 \\
\hline $\mathrm{I} 2$ & 30.75 & 32.60 & 33.40 & 32.25 \\
\hline $\mathrm{I} 3$ & 31.95 & 32.65 & 34.84 & 33.15 \\
\hline Mean & 29.67 & 32.38 & 33.91 & \\
\hline \multirow[b]{2}{*}{$\operatorname{SEm}( \pm)$} & I & V & $\mathrm{Ix} \mathrm{V}$ & \\
\hline & 0.21 & 0.15 & 0.41 & \\
\hline $\mathrm{CD}(5 \%)$ & 0.64 & 0.45 & 1.22 & \\
\hline
\end{tabular}

Note: $\mathrm{I} 1=$ Irrigation at $0.4 \mathrm{IW} / \mathrm{CPE}, \mathrm{I} 2=$ Irrigation at $0.8 \% \mathrm{IW} / \mathrm{CPE}, \mathrm{I} 3=$ Irrigation at $1.0 \mathrm{IW} / \mathrm{CPE}$ and $\mathrm{V} 1=$ Variety Prajwal, V2 = Variety Calcutta single, V3 = Variety Calcutta double

Table.5 Water use and water use efficiency of tuberose under different irrigation regimes

\begin{tabular}{|l|c|c|c|c|c|c|}
\hline Treatment & $\begin{array}{c}* \text { Profile } \\
\text { contributi } \\
\text { on }(\mathrm{mm})\end{array}$ & $\begin{array}{c}\text { Irrigation } \\
(\mathrm{mm})\end{array}$ & $\begin{array}{c}\text { Rainfall } \\
(\mathrm{mm})\end{array}$ & $\begin{array}{c}\text { Total } \\
\text { water use } \\
(\mathrm{mm})\end{array}$ & $\begin{array}{c}\text { Economic } \\
\text { yield } \\
\text { (spike/plot) }\end{array}$ & $\begin{array}{c}\text { Water use } \\
\text { efficiency } \\
\text { (spike/plot/cm) }\end{array}$ \\
\hline $0.4 \mathrm{IW} / \mathrm{CPE}$ & 22.70 & 240 & 1319 & 1581.7 & 30.57 & 0.193 \\
\hline $0.8 \mathrm{IW} / \mathrm{CPE}$ & 32.10 & 510 & 1319 & 1861.1 & 32.25 & 0.173 \\
\hline $1.0 \mathrm{IW} / \mathrm{CPE}$ & 35.70 & 630 & 1319 & 1984.7 & 33.15 & 0.167 \\
\hline
\end{tabular}

*AICRP on Water Management, BCKV, 2009-2010, PP: 40-46.

Table.6 Economics of tuberose cultivation under different moisture regimes

\begin{tabular}{|l|c|c|c|}
\hline \multirow{2}{*}{ Particulars } & \multicolumn{3}{|c|}{ Irrigation levels } \\
\cline { 2 - 4 } & $0.4 \mathrm{IW} / \mathrm{CPE}$ & $0.8 \mathrm{IW} / \mathrm{CPE}$ & $1.0 \mathrm{IW} / \mathrm{CPE}$ \\
\hline Cost of Cultivation (Rs/ha) & 125000 & 135000 & 140000 \\
\hline Yield (Spike/ha) & 254750 & 268750 & 276250 \\
\hline Selling price (Rs./ spike) & 0.75 & 0.75 & 0.75 \\
\hline Gross return (Rs./ha) & 191062 & 201562 & 207187 \\
\hline Net return (Rs/ha) & 66062 & 66562 & 67187 \\
\hline Benefit : cost ratio & $0.53: 1$ & $0.49: 1$ & $0.48: 1$ \\
\hline
\end{tabular}




\section{Spike per plant}

The different irrigation schedules regardless of the crop varieties on the number of spike per plot were significant (Table 4). The maximum spike per plot was recorded at 1.0 IW/CPE which gave about 33.15 number of spike per plot, which was superior to $0.8 \mathrm{IW} / \mathrm{CPE}$ (32.25) and $0.4 \mathrm{IW} / \mathrm{CPE}$ (30.57). The lowest number of spike per plot was shown by the drier moisture regimes, while the highest number of spike per plot was recorded by the wetted moisture regimes. The number of spike per plot, irrespective of moisture regimes, among the three varieties tested was significant with each other. The maximum number of spike per plot was recorded by Calcutta double (33.91), followed by that of Calcutta single (32.38) and Prajwal (29.67). The interaction between the irrigation schedules and the varieties on the number of spike per plot was significant. However, maximum number of spike per plot (34.84) was recorded by Calcutta double irrigated at the irrigation schedule of 1.0 IW/CPE.

\section{Water use and water use efficiency}

The higher water use was observed at higher levels of irrigation water application (Table 5). Conversely, the highest water use efficiency was observed at lower levels of irrigation application in comparison to higher levels of irrigation ascribed due to more application of irrigation water to crop.

\section{Economics}

The economic analysis of tuberose under three irrigation levels is given in (Table 6) for computing the net profit and benefit cost ratio, the prevailing cost of cultivation and the gross return from the flower crop as per market value was taken into consideration. The result showed that the higher net reruns was recorded at higher moisture regime (IW/CPE at 1.0) followed by intermediate moisture regime (IW/CPE at 0.8) and lower moisture regime (IW/CPE at 0.4). However, the benefit-cost ratio was just opposite to net return values. This indicated that the economic yield of tuberose was not high enough in response to the higher irrigation regimes, thereby giving lesser gross return as well as the net return values as compared to the lower moisture regime.

The application of irrigation based on IW/CPE ratio revealed that plant height of tuberose consistently increased with the increasing moisture regimes. However, the highest plant height of 54.97 was obtained with the irrigation at 1.0IW/CPE ratio, which was superior to other irrigation treatments.

The application of irrigation based on IW/CPE ratio revealed that the leaf/plant of tuberose consistently increased with increasing moisture regime. However, the highest leaf per plant of 105.12 was obtained with the irrigation schedule 1.0 IW/CPE which was superior to other irrigation treatments. However, variety Calcutta double showed the highest value of leaf per plant irrigated at higher moisture level. Maximum length of stalk $(79.7 \mathrm{~cm})$ was observed in the irrigation schedule of 1.0 IW/CPE which was superior to other two irrigation schedules (Table 6). Maximum diameter of stalk $(3.38 \mathrm{~cm})$ was found by the irrigation schedule of 1.0 IW/CPE followed by that of $3.35 \mathrm{~cm}$ at $0.8 \mathrm{IW} / \mathrm{CPE}$ and $3.30 \mathrm{~cm}$ at $0.4 \mathrm{IW} / \mathrm{CPE}$.

The stalk diameter of three varieties of tuberose, irrespective of irrigation schedules, was significantly influenced. The highest diameter $(3.62 \mathrm{~cm})$ was registered by the variety Calcutta double and that was superior to other two varieties under tested. Maximum diameter of spike $(3.35 \mathrm{~cm})$ was observed at $1.0 \mathrm{IW} / \mathrm{CPE}$ ratio and the minimum diameter of spike $(3.25$ $\mathrm{cm})$ was shown at irrigation schedule of 0.4 IW/CPE ratios. The varietal effects in promoting the diameter of spike, irrespective of irrigation levels, were significantly influenced. The highest diameter of $3.41 \mathrm{~cm}$ was recorded by Calcutta double followed by that of $3.36 \mathrm{~cm}$ by Calcutta single and $3.15 \mathrm{~cm}$ by Prajwal. 
Maximum flower per spike (31.80) was observed at 1.0 IW/CPE ratio and the minimum number of flower/ spike (31.40) was recorded by irrigation schedule of 0.8 IW/CPE ratios. The varietals effects in promoting the number of flower per spike, irrespective of irrigation levels, were significantly influenced. The highest number of flower per spike (33.1) was recorded by Calcutta double followed by that of Calcutta single (31.50) and Prajwal (30.20). The maximum spike per plot was recorded at 1.0 IW/CPE which gave about 33.15 number of spike per plot, which was superior to 0.8 IW/CPE (32.25) and 0.4 IW/CPE (30.57).The maximum number of spike per plot was recorded by Calcutta double (33.91), followed by that of Calcutta single (32.38) and Prajwal (29.67). However, the benefit-cost ratio was just opposite to net return values. This indicated that the economic yield of tuberose under higher moisture level was not high enough/ or optimal in response to the higher irrigation regimes, thereby giving lesser gross return as well as the net return values as compared to the lower moisture regime.

\section{References}

Ahmad, S.G. (1996). Water requirement estimation for onion. News-LetterNational-Horticultural-Research-andDevelopment-Foundation: 16(4): $12-18$.

Banker, G.J. and Mukhopadhyay, A. (1980). Varietal trial on tuberose (Polianthes tuberose L.). South Indian Horticulture. 28 (4): 150-151.

Biswas, B., Kumar, P.N. and Bhattacharjee, S.K. (2002). Tuberose. Published by I.C.A.R. New Delhi: 1 - 2.

Dalal, S R., Dalal, N.R., Rajurkar, D.W., Golliwar, V.J. and Patil, S.R. (1999). Effect of nitrogen levels and gibberellic acid on quality of flower stalk of tuberose (Polianthes tuberosa L.) Journal of Soil and Crop., 9 (1): 88-90.

Denis DM and Kumar JL. 2007. Yield response of drip irrigated potato under variable irrigation levels. Journal of Soil and Water Conservation. 6(2): 64-69.
FAO, (1986). Irrigation water management training manuals: Series No: 3 S2022/E.

Farina, E., Cervelli,C.(1994). Growth and water requirements of carnation cultivated on raised benches. Acta-Horticulturae: 361, 478: 485.

Halepyati, .A.S., Sujatha, K., Prabhakar, M. (1995). Growth, yield, water relations and its use in tuberose (Polianthes tuberosa) as influenced by irrigation regime and nitrogen level. Indian Journal of Agricultural Sciences: 65 (12): 866 - 869.

Kong. Qing Xin., Zhang. Hai Lin., Chen. Fu., Song. Zhen Wei. (2009). Estimation of main crop water requirement in Beijing based on SIMETAW model. Journal of China Agricultural University: 14 (5): $109-115$.

Malik, R.S., Bhandari, A.R. (1994). Water requirement of pea (Pisum sativum) in Inceptisol of mid-Himalayas. Indian Journal of Agricultural Sciences: 64 (12): $847-849$.

Mishra J N, Paul J C and Pradhan P C. 2008. Response of cashew to drip irrigation Orissa and mulching in coastal Orissa. Journal soil and Water Conservation: 7(3): 36-40.

Mostert, P.G., Hoffman, J.E. (1997). Water requirements and irrigation of mature mango trees. Acta-Horticulturae: 455, 331: 338 .

Munikrishnappa, P.M., Gowda, M.C., Farooqi, A.A., Reddy, Y.A.N. (2002). Fertigation studies in tuberose cv. Single. IndianJournal-of-Horticulture: 59 (1): 106 110.

Nabard (1997). A report on floriculture in eastern and north eastern region. Publish by Nabard, Calcutta.

Naggar, E.1., A.I., Byari, S.H. (2009). Impacts of irrigation frequencies and weed control, in field grown tuberoses, in the Western Region of Saudi Arabia. AlexandriaJournal-of Agricultural-Research: 54 (1): $49-74$.

Roso, J.W. (1903-1095). Studies of Mexican and control American Plant. Contribution from the United States National Herbarium, 8:1- 
55.

Sharma, D.K., Singh, K.P., Joshi, H.C. (2006). Response of pre-sown distillery effluent irrigation on vegetative and floral characters of tuberose (Polianthes tuberosa L.).Journal-of-Ornamental Horticulture: 9 (2): 139 - 141

Sharma, S.K., Abha Tikkoo., Kapoor, A.K., Dahiya, S.S. (2003). Effect of sodic water, FYM and gypsum on soil properties and performance of tuberose. Haryana Journal of Horticultural Sciences: 32 (3/4): $219-221$.

Singh, M.C. and Singh, K.P. (2006). Commercial cultivation of tuberose. Floricultural Today. Pp. 37-38.

Song, Zhen Wei., Zhang, Hailin., Huang, Jing., Chen, Fu (2009). Characters of water requirement for main crops and field water balance in Beijing region. Research of Agricultural Modernization, 30 (4): $461-465$.

Wang, Pei Xing., Sheng, Ping., Hong, Jia Lian (2003). Trickle irrigation experiment and water consumption estimation on greenhouse vegetable. Journal of Shanghai Jiaotong University Agricultural Science: 21 (1): 64 - 69.

Yadav, A.C., Batra, B.R., Malik, Y.S. (1997). Irrigation requirement of fennel (Foeniculum vulgare Mill). Water and nutrient management for sustainable production and quality of spices: proceedings of the national seminar, Madikeri, Karnataka, India. Pp. 136 140.

Yadav, A.C., Batra, B.R., Malik, Y.S. (1997). Irrigation requirement of fennel (Foeniculum vulgare Mill). Water and nutrient management for sustainable production and quality of spices: proceedings of the national seminar, Madikeri, Karnataka, India. Pp. 136 140.

Tan, C.S., (1980). Estimating crop evapotranspiration for irrigation scheduling. Agriculture Canada, 25: 2629. Karnataka Journal of Agricultural Sciences: 20 (3), 2007

Tan, C.S. and Layne, R.E.C., (1981). Application of a simplified evapotranspiration model for predicating irrigation requirements of Peach. Horticultural Science: 16: 172-173.

Allen, R.G., Pereira, L.S., Raes, D. and Smith, M., (1998). Crop evapotranspiration, guidelines of computing crop water requirement. Irrigation and Drainage paper: 56, FAO, Rome.

Gorad, C.T., Varshneya, M.C. and Bote, N.L., (1995). Evapotranspiration of post-rainy season sorghum under different soil moisture levels. Journal of Maharashtra Agricultural Universities: 20: 74-77.

Rao, V.P. and Sondge, V.D., (1995). Crop coefficients for sesame. Journal of Maharashtra Agricultural Universities: 20: 46-49.

Sondge, V.D., Rodge, R.P., and Dahiphale, V.V., (1992). Response of safflower varieties to irrigation schedules. Journal of Maharashtra Agricultural Universities: 17: 9-12.

Suneethadevi, K.B. and Praveen Rao, V., (2002). Relationship between actual evapotranspiration (ETa) of corn and reference evapotranspiration (ETo) derived from empirical formulae. Journal of Soils and Crops: 12: 318-322.

\section{How to cite this article:}

Rubina Khanam, Dipa Kundu, Umalaxmi Thingujam and Patra, S.K. 2017. Effect of Different Irrigation Level on Growth, Yield and Water Use Efficiency of Tuberose in Lower Gangetic Plain of West Bengal, India. Int.J.Curr.Microbiol.App.Sci. 6(8): 1944-1952. doi: https://doi.org/10.20546/ijcmas.2017.608.230 